\title{
Evaluating a single camera system for quantifying ebullition from gassy freshwater sediments
}

\author{
William de Wit
}

This manuscript was prepared by a student from the School of Engineering working at the St. Lawrence River Institute of Environmental Sciences in Cornwall, Ontario.

\begin{abstract}
A single camera system for measuring ebullition from freshwater gassy sediments is presented. The employment of relatively inexpensive video equipment along with laboratory-based analysis techniques were evaluated for use in quantifying ebullition from freshwater gassy sediments in the St. Lawrence River near Cornwall, ON.
\end{abstract}

$\mathrm{T}$ The St. Lawrence River is one of the 25 largest rivers in the world, flowing from the Great Lakes, the world's largest lake system, to the Atlantic Ocean. ${ }^{1}$ Areas of the Upper St. Lawrence River are known to have depositional zones in which the decomposition of organic matter is resulting in methane gas ebullition. ${ }^{5}$ Bubbles form in sediments when the partial pressure of the gases produced exceeds the sum of the hydrostatic and atmospheric pressures. They are subsequently thrust up through the sediment once their buoyant force becomes sufficiently large. ${ }^{4}$

\section{CONCEPTUAL DESIGN/METHODOLOGY}

\section{Objective}

The objective was to evaluate the usefulness of a single camera observation platform along with traditional laboratory-based reactor and fermentation engineering principles to quantify ebullition from freshwater gassy sediments.

\section{Major components}

An AUC-60 underwater video camera and AUM-522 video monitor (Atlantis Underwater Video Systems ${ }^{\circledR}$ ) were used in tandem with a subsurface gas collector design to acquire video and images as well as capture the volume of gas observed evolving from the sediment. The gas collector design was adapted from that of Jari Huttenen et al. in $A$ novel sediment gas sampler and a subsurface gas collector used for measurement of the ebullition of methane and carbon dioxide from a eutrophied lake. An $80 \mathrm{~cm}$ PVC (polyvinylchloride) pipe of $2.5 \mathrm{~cm}$ diameter (3/4") overlapped the narrow end of a $30 \mathrm{~cm}$ diameter plastic funnel. Attached around the bottom of the funnel, was a 5 lb weight to maintain the collector in an upright position appropriate for collecting bubbles. A $60 \mathrm{~mL}$ Luer Lok® syringe overlapped on the other end of the PVC pipe with an attached Luer 2way stopcock. This allowed the true amount of gas collected to be measured. The gas collector was suspended 1 to 3 feet above the sediment from the anchored boat. The camera was fixed to the gas collector so as to record from a position where both the sediment and the edge of the gas collector were in view to distinguish between bubbles that entered the collector and those that did not. A ruler was attached to the collector to include a known dimension in the camera's immediate field of view.

\section{Analysis Techniques}

The video monitor was connected to a model 2960CLV video cassette recorder (Sylvania ${ }^{\circledR}$ ) which recorded video for the entire duration of the collector deployment. Images of the bubbles were then acquired using an Asus TV tuner chipset on a PC (see Figure 1). These images were then analysed with ImageJ, an open-source Java-based image analysis program developed at the National Institutes of Health. ${ }^{2}$ Applying a calibration vector to each image using the know dimension of $1 \mathrm{~cm}$ (from the ruler attached to the collector), it was possible to acquire the height and width dimensions of each bubble that entered the collector. With these dimensions, an equivalent diameter was acquired for each bubble. The equivalent diameter, $D_{\text {eq }}$ is given by the following equation:

$$
D_{\text {eq }}=h *\left(3 a^{2}+h^{2}\right) /\left(h^{2}+2 a^{2}\right)
$$


Where $h$ is the height of the bubble and $a$ is half of the width of the bubble in centimeters. ${ }^{3}$ The sum of these volumes is the theoretical volume of gas collected. As seen in Figure 1, bubbles are apparent immediately in front of the ruler as they rise from the sediment (white and grey) into the collector (black).

\section{DISCUSSION AND RECOMMENDATIONS}

From 5 images captured from the video recording, 18 bubbles were observed and analyzed. The bubbles observed behaved as independent bubbles (non-swarm behaviour and did not coalesce) and were not of consistent size or shape. Most of the bubbles appeared elliptical, although some appeared circular. This is why it was necessary to acquire the height and width of each bubble and make use of an equivalent spherical diameter for each bubble regardless of apparent shape. The entire opening of the collector was in the field of view of the camera. Therefore none of the bubbles that entered the collector were unnoticed. By reading the $60 \mathrm{~mL}$ syringe that was mounted to the collector after 1 hour, $2 \mathrm{~mL}$ of gas was observed to have been collected which translates to a rate of appearance of $679 \mathrm{ml} / \mathrm{m}^{2} /$ day. The observed measurement is only accurate to one decimal place as it is difficult to read the volume of gas collected in a $60 \mathrm{~mL}$ syringe to any greater degree of accuracy. The results of the analysis yielded a theoretical volume of $2.13 \mathrm{~mL}$, or approximately a $6 \%$ error. The calculated rate of appearance of gas from the theoretical data is $724 \mathrm{ml} / \mathrm{m}^{2} /$ day which appropriately represents the rate of appearance of gas historically observed in the region. ${ }^{6}$ The experiment took place on August 10, 2007. The depth of the sampling location is approximately nine meters and is between two nearby (within 20m) independent identical gas collectors to the east and west, which have collected an unweighted average of about $603 \mathrm{ml} / \mathrm{m}^{2} /$ day and $932 \mathrm{ml} / \mathrm{m}^{2} /$ day respectively in August 2007 (Table 1). More experiments of this type should be done to ensure reproducibility of the results. It is also recommended that any further experiments of this type be conducted at different times, weather conditions and water depths to assess any lighting differences that may affect image processing techniques.

\section{Acknowledgments}

I would like to thank the St. Lawrence River Institute of Environmental Sciences for the opportunity to conduct these experiments as well as for the use of their equipment. I would also like to thank Dr. Jeff Ridal, Dr. Peter Hodson, Dr. Linda Campbell, Dr. Jules Blais, Dr. David Lean and Dr. Brian Hickey under the Best in Science Grant from the Ministry of the Environment. I would also like to thank Roxanne Razavi, Jonathan Martin, Emma Brown, Ray Gauthier and Jason Szwec for their contributions to the system design and in the field, their help was much appreciated.

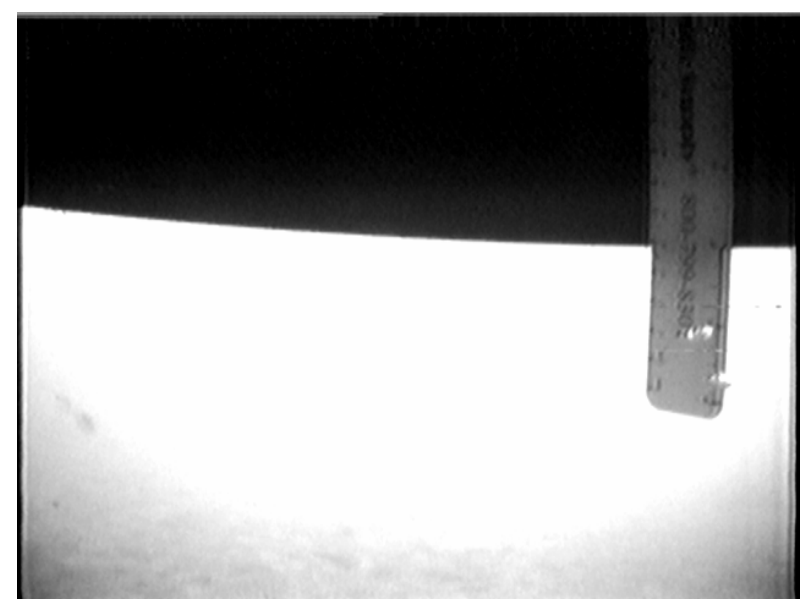

Figure 1 - Bubbles entering the gas collector (black) from the sediment (white and grey) immediately in front of the ruler.

Table 1 - Rates of Appearance of Gas

\begin{tabular}{|c|c|}
\hline Sampling Location & Rate of Appearance of Gas \\
\hline $\begin{array}{c}\text { Observed Study Site } \\
(18521309 \mathrm{E}, 4984353 \mathrm{~N})\end{array}$ & $679 \mathrm{ml} / \mathrm{m}^{2} /$ day \\
\hline $\begin{array}{c}\text { Theoretical Study Site } \\
(18521309 \mathrm{E}, 4984353 \mathrm{~N})\end{array}$ & $724 \mathrm{ml} / \mathrm{m}^{2} /$ day \\
\hline $\begin{array}{c}\text { East Reference Site } \\
(18521300 \mathrm{E}, 4984332 \mathrm{~N})\end{array}$ & $603 \mathrm{ml} / \mathrm{m}^{2} /$ day \\
\hline $\begin{array}{c}\text { West Reference Site } \\
(18521260 \mathrm{E}, 4984318 \mathrm{~N})\end{array}$ & $932 \mathrm{ml} / \mathrm{m}^{2} /$ day \\
\hline
\end{tabular}

\section{REFERENCES}

1. DeVilliers, M. 2003. Water: The fate of our most precious resource. McClelland and Stewart Ltd. Toronto ON.

2. Girish V., Vijayalakshmi A. 2004. Affordable Image Analysis using NIH Image/ImageJ. Indian Journal of Cancer. 41:1 pp47

3. Hayward, G. 2006. ENGG 3160 Biological Engineering Systems 2 Class Notes. University of Guelph. Guelph, ON.

4. Huttunen J., Lappalainenb K., Saarijarvi E., Vaisanen T., Martikainena P. 2001. A novel sediment gas sampler and a subsurface gas collector used for measurement of the ebullition of methane and carbon dioxide from a eutrophied lake. The Science of the Total Environment. 266 pp.153-158

5. Poissant L., Constant P., Pilote M., Canario J., O'Driscoll N., Ridal J., Lean D. The Ebullition of hydrogen, carbon monoxide, methane, carbon dioxide and total gaseous mercury from Cornwall Area of Concern.

6. Razavi R. Personal Communication. August 10, 2007. St. Lawrence River Institute of Environmental Sciences. Cornwall, ON. 